\title{
THE DEVELOPMENT TREND OF OVER TOURISM IN THE WORLD
}

\author{
Dugienko N., Brich A. S. \\ Zaporizhzhia National University \\ Ukraine, 69600, Zaporizhzhia, Zhukovsky str., 66 \\ dugienkonata@ukr.net,max12365460@gmail.com \\ ORCID 0000-0002-4551-5548, ORCID 0000-0003-1260-2861
}

Key words:

mass tourism, over tourism, the tourism sector, the trend towards growth, peace, culture.
The article examines the state of the tourism sector in the world in the 21 st century. Now it is impossible to even imagine a world without tourism; none of the countries is left without the attention of travelers. This topic is very relevant for each of the countries of Europe, and for most countries of the world as a whole. Tourism occupies an important place in the economy of countries, and for some countries, tourism is the main source of filling the country's budget and accounts for more than $60 \%$ of GDP. The article analyzes the main trends in the further development of the tourism sector and identifies problems related to mass tourism. The negative impact of tourism on cultural attractions, traditions and the life of the local population as a whole is studied. The study highlights the main factors that contribute to mass tourism. The article notes the need to introduce certain barriers that will prevent such a large number of travelers, but if this does not happen, the uniqueness of nature and the identity of Nations will gradually be destroyed. The scientific and practical value of the research results consists in the fact that ways to overcome the problem of overtourism can be used by countries that really need it.

\section{ТЕНДЕНЦІЯ РОЗВИТКУ ОВЕРТУРИЗМУ У СВІТІ}

\author{
Дугіснко Н. О., Бріч А.I. \\ Запорізький національний університет \\ Украӥна, 69600, м. Запоріжжя, вул. Жуковського, 66
}

\section{Ключові слова:}

масовий туризм, овертуризм, сектор туризму, тенденція до зростання, світ, культура.

\begin{abstract}
У статті досліджується стан сектору туризму в світі у 21 сторіччі. Зараз неможливо навіть уявити світ без туризму, жодна 3 країн не залишена без уваги подорожуючих. Дана тема $\epsilon$ дуже актуальною для кожної 3 країн Європи, та для більшості країн світу вцілому. Туризм посідає вагоме місце у економіці країн, а для деяких туризм $є$ основним джерелом наповнення бюджету країни і складає більше $60 \%$ ВВП. У статті проаналізовано основні тенденції подальшого розвитку туристичного сектору та виявлено проблеми, які пов'язані 3 масовим туризмом. Досліджено негативний вплив туризму на культурні пам'ятки, на традиції і на життя місцевого населення загалом. У ході дослідження виділено основні чинники, що сприяють масовому туризму. У статті наголошується на необхідності введення певних бар'єрів, що перешкоджатимуть такій кількості подорожуючих, якщо ж такого не відбудеться, то унікальність природи та самобутність націй буде поступово знищуватися. Наукова та практична цінність результатів дослідження полягає у тому, що шляхи подолання проблеми овертуризму можуть бути використані країнами, які цього дійсно потребують.
\end{abstract}

\section{Problem statement}

In the modern conditions of globalization, the tourism sector is developing too actively. Mass tourism is gaining in scale, and therefore it needs to be studied and researched. The urgency of reducing overt tourism is to protect the environment, preserve culture and improve the social situation in cities.

\section{Analysis of recent studies and publications}

Many scientists and researchers have studied the problems of overturism: Andrew Sheivakhman [1], Ramon Estalella, Evgenia Lisitsina, Alina Khorosheva, Dmitry and Anastasia Timushev [2], and others. But at the same time, the problem is quite young, and therefore many issues require more in-depth study and research.

\section{Articulating the goals of the article}

The objective and objective of the research is to determine the current state of tourism in the world, study the impact of mass tourism on society and provide suggestions for overcoming the negative consequences associated with the phenomenon of over tourism.

\section{Presentation of the main research material}

Travel has long been an integral part of our lives. The World Travel and Tourism Council (WTTC) estimates that tourism is one of the top five sources of income for $80 \%$ of countries, especially Europe, the Middle East and the United States. Today, tourism is a key factor in the development and prosperity of countries. The tourism industry accounts for about $10 \%$ of employment worldwide. 
According to the trends, it is expected that tourism will continue to develop actively in the future. The key factors driving this development are: population growth, improved living standards, expanded and improved infrastructure, reduced travel prices, and more. In the total number of trips, $60 \%$ are leisure-related trips, and approximately $30 \%$ are business trips.

At the moment, there is a rather uneven development of tourism in the world. Most tourist flows are formed and carried out between highly developed countries. Approximately $2 / 3$ of trips are made in developed countries, and only $1 / 3$ in developing countries [3]. The UNWTO report shows that in 2018, $48 \%$ of all global arrivals are in Europe, $25.6 \%$ in the Asia-Pacific region, $16.8 \%$ in the Americas, and only $2.9 \%$ in the Middle East and $3.2 \%$ in Africa [4].

The graph (Fig. 1) shows the dynamics of growth in the number of tourists arriving in different countries, in the world as a whole, for the period from 1990 to 2018. The data source is a report from the world tourism organization (UNWTO) [4].

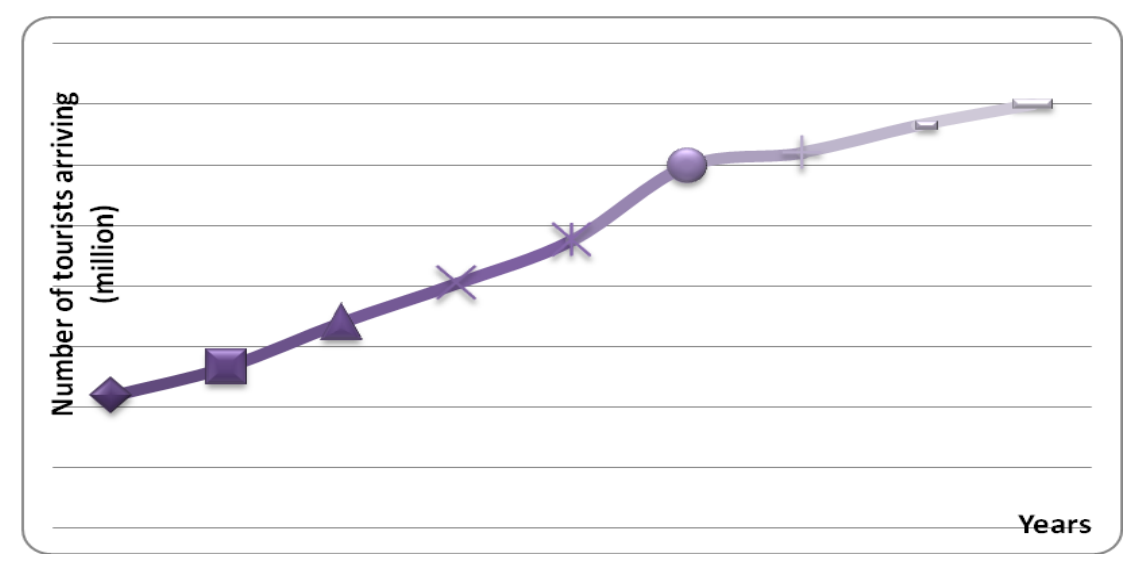

Fig. 1 - Dynamics of tourist arrivals in the world as a whole (million people) [4]

The graph clearly shows a rapid upward trend. It is obvious that tourism will not decline in the near future. This positive trend also has negative consequences.

Despite huge revenues from the tourism sector, many countries face a serious problem: overtourism.

The word "overtourism" first appeared in a 2016 in article Skift by reporter Andrew Scheivachman, in which he explored the dangers of tourism in Iceland. In the article, the reporter explains how Iceland emerged from a serious financial crisis in 2008 with the help of a rapid growth in tourism, and how the population of 350,000 people should receive about 1.6 million tourists in 2016. Negative consequences for the country are also considered: economic, environmental, socio-cultural, and impact on the local population [3].

The term over tourism is used to describe the negative effects of mass tourism associated with the growing popularity of specific places in the world. After decades of uncontrolled tourism, it has crossed the border, and tourism creates more problems than benefits.

The excessive number of tourists leads to the gradual physical and cultural degradation of popular places, the destruction of their identity. Environmental damage is caused to nature and the quality of life of people living in or near these places is deteriorating [4].

Across Europe, the number of social movements and protests is growing, and slogans such as "Tourists! Go back home!" Organizations are being created to fight tourism, such as the Assembly of Neighborhoods for Sustainable Tourism (ABTS) and the Network of Southern European Cities against tourism (SET) [5].

For a broader view of mass tourism, the following are examples of protests and movements aimed at combating overtourism.
The situation in Spain is very tense right now. Violent slogans about the problem are often found on buildings, for example: "Tourists, you are terrorists" or "there are no room for tourists". If the fight against tourists in the Balearic Islands is still quite peaceful, then in Catalonia the tourist may suffer. Local youth organizations spoil tourists ' rented bicycles, pour glue into the locks of suitcases and luggage storage, throw paint and smoke bombs at the hotel where tourists stay. The worst was the attack in Barcelona. Four masked men threatened the driver and passengers with weapons, punctured tires and wrote "Tourism kills neighborhoods" on the windshield. Actions of this type were also held in Valencia [6].

The most popular places among tourists in Europe are Venice, Croatian Dubrovnik, the Isle of Skye in Scotland. Amsterdam, Barcelona, Rome, Paris, Palma de Mallorca and other European cities are also affected by mass tourism. Victims are the island of Phi Phi in Thailand, the mountain peaks of the Andes, Kuala Lumpur (Malaysia), Kyoto (Japan), Jakarta (Indonesia) and many other places in the world [7].

The main reasons for such mass tourism are:

1. The emergence of low-cost airlines - budget airlines, the prices of which start from 5 euro. Europe is oversaturated with such carriers. The reason for such low ticket prices is that the tax and VAT are not deducted from aviation fuel;

2. Availability of cheap housing, such as the Airbnb housing search service. Tourists who have a limited budget, usually young people, prefer cheap hostels, camping, or a small room. And some even live for free, thanks to couchsurfing. As a result, real estate purchase prices are rising, and it is difficult for the local population to find housing at a favorable price. And in Barcelona's strong push for infrastructure led to the fact that property 
owners were evicted local residents in order to rent properties to tourists.

3. Fashion trends, TV series, Instagram. Bloggers are too active in influencing the tourism industry. For example, a few years ago, the "rainbow mountains" in Peru were almost unknown to tourists. And in 2016, when several bloggers got there and photos quickly spread around the world - thousands of tourists visit these mountains every day. Another example is Phi Phi island in Thailand. After the release of the film "Beach", the island was crowded with tourists and the authorities were forced to temporarily close it to restore nature. Based on statistics, $20 \%$ of travelers in 2018 used information from travel blogs. [8].

4. Of course, Chinese tourists, from the influx of which European capitals suffer daily. At the beginning of the 21st century, 10.5 million Chinese people traveled per year, and in 2017 this figure was 145 million. According to forecasts Of the Institute of tourism of China in 2030, this figure will be 400 million per year. [9].

5. The growth of mass tourism affected by cruise ships. They are allowed to use very cheap and polluting fuel. This allows you to maintain low costs and make fairly loyal ticket prices. Thousands of tourists' daily wander through the streets of historical places, usually they do not spend much money and return to the ship for lunch [10].

Many countries are already actively reviewing their tourism policies in favor of wealthy tourists - in order not to lose income and reduce the number of tourists at the same time. Countries introduce additional taxes, quotas, and restrictions on cultural attractions, and some sites are closed to tourists altogether. New or revised taxation mechanisms, penalties associated with new local laws, and "demarketing" are being implemented, resulting in destinations focused on attracting fewer tourists with high costs and low returns. The most popular method of reducing tourism is to introduce or increase taxes on housing, and for landlords a strict ban on renting out housing without licenses.

Croatia is actively developing a network of bike paths, which will help to evenly distribute the flow of tourists.

In Venice, there are turnstiles to regulate the movement of pedestrians. Even the authorities of Venice banned large cruise ships from using the city terminal, because it spoils the Foundation of buildings. Tourists are also forbidden to use bicycles, feed pigeons and walk around the city in bathing clothes.
The Dutch authorities decided not to advertise the country as a tourist destination. Amsterdam is introducing ads for less popular places, and some areas are planning to close altogether. The famous "I Amsterdam" sign was moved from the city center to less well-known areas in 2018 to distract tourists away from the center. The state is taking measures to reduce tourists in the red-light District, and restrictions have been imposed on the number of people in groups [11].

In 2016, Santorini introduces restrictions on visitors from cruise ships up to 8,000 people per day. In the Cinque Terre (Italy), the authorities introduced a limit of 1.5 million visitors per year, because in 2015 these villages were visited by more than 2.5 million people. Government of Peru in Machu Picchu allows groups of 16 people to visit this place for a limited time.

In France, tourists do not like because of their addiction to alcohol and therefore in Nice banned the sale and drinking of alcoholic beverages from 8 PM to $5 \mathrm{am}$.

The Nepalese government has banned solo climbers from climbing Mount Everest, and foreign tourists are only allowed to climb with a guide. The impetus for this was hundreds of kilograms of garbage collected by the local population after tourists [12].

Lyon is developing routes for visitors to the city to relieve the city center and main streets. These are not all measures that are implemented by the governments of countries to improve the lives of the local population and preserve cultural monuments [13].

\section{Conclusions}

Summing up all the above we see that for many countries the fight against over tourism should become a priority. But unfortunately, despite the growing outcry, tourism promotion continues - and hordes of tourists continue to descend on cities, beaches, and other natural wonders.

Managing the flow of tourists seems an incredible and undesirable task, but governments are actively trying to improve the lives and conditions of local residents and perhaps in the future the world will get rid of this problem.

For our part, as tourists, we must respect the culture and heritage of other peoples. We must be polite to the local population and understand that they are experiencing great discomfort from tourists. We have no right to damage cultural objects. The tourist must understand the local customs and be sure to adhere to them.

\section{References}

1. Andrew Sheivachman (2016) Islandiia ta vyprobuvannia turyzmu 21-ho stolittia [Iceland and the trials of $21 \mathrm{st}$ century tourism]. skift.com Retrieved from https://skift.com/iceland-tourism/ [in English].

2. Dmitry Nikitchenko (2018) Overturizm - chto eto takoye? [Overtourism - what is it?]. paikea.ru Retrieved from http://paikea.ru/overtourism/ [in Russian].

3. Zhmurko Irina (2009) Tendentsiï rozvitku mizhnarodnoï torgivli turistichnimi poslugami v umovakh dinamizatsii. [Trends in the development of international trade in tourist services in the context of dynamization]. Industriya gostinnosti v kraïnakh Cvropi - Hospitality industry in Europe, 36-38 [in Ukrainian].

4. Ofitsiinyi sait Vsesvitnoi turystychnoi orhanizatsii [United Nations World Tourism Organization]. www.unwto.org Retrieved from https://www.unwto.org/ [in English].

5. Laura Hood (2018) Overturizm: zrostayucha globalna problema [Overtourism: a growing global problem]. theconversation.com Retrieved from https://theconversation.com/overtourism-a-growing-global-problem100029[in English].

6. Yuriy Kogalov (2017) Turistam bolshe ne rady [Tourists are no longer welcome]. rg.ru Retrieved from https://rg.ru/2017/08/10/v-evropejskih-gorodah-nachalis-protesty-protiv-inostrannyh-turistov.html [in Russian]. 
7. Turizm v tolpe: chto takoye overturizm i chto s etim delat [Tourism in the crowd: what is overt tourism and what to do about it], (2019). piligrim.ua Retrieved from https://piligrim.ua/advice/turizm-v-tolpe-chto-takoeoverturizm-i-chto-s-etim-delat [in Russian].

8. Anastasiya Bazhenova (2019) Overturizm. "Brekzit" i instagram: chto budet aktualno v mire puteshestviy 2019 goda [Overtourism. Brexit and Instagram: what will be relevant in the world of travel in 2019]. samokatus.ru Retrieved from https://samokatus.ru/2019/04/trends2019/ [in Russian].

9. Pavel Polukhin (2018) Chto takoye overturizm i ego vliyaniye na puteshestviya [What is overturism and its impact on travel]. $\quad$ zen.yandex.ru retrieved from https://zen.yandex.ru/media/id/5a1bcf38865165725315038b/chto-takoe-overturizm-i-ego-vliianie-naputeshestviia-5b42f7a6eafc3100aadc0060 [in Russian].

10. Justin Francis (2017) Overturizm-chto eto takoye. i kak ego izbezhat? [Overturizm - what is it, and how can we avoid it?]. www.responsibletravel.com Retrieved from https://www.responsibletravel.com/copy/what-isovertourism [in English].

11. Richard Quest \& Tamara Hardingham-Gill (2019) Kak Amsterdam boretsya s massovym turizmom [How Amsterdam is fighting back against mass tourism]. edition.cnn.com Retrieved from https://edition.cnn.com/travel/article/amsterdam-overtourism [in English].

12. Johnny Jet (2018) Kak overturizm vliyayet na puteshestviya po populyarnym napravleniyam? [How Is Overtourism Impacting Travel To Popular Destinations?]. www.forbes.com Retrieved from https://www.forbes.com/sites/johnnyjet/2018/08/20/how-is-overtourism-impacting-travel-to-populardestinations/\#21730ec635b8 [in English].

13. Overturizm [Overtourism]. www.abcfact.ru Retrieved from https://www.abcfact.ru/9352-overturizm.html [in Russian].

14. Yuzhnoyevropeyskiye goroda i zainteresovannyye storony obyedinyayut svoi usiliya protiv massovogo turizma [South European cities and stakeholders join forces against mass tourism]. www.thelocal.es Retrieved from https://www.thelocal.es/20180427/south-european-cities-and-stakeholders-join-forces-against-mass-tourism [in English].

15. Ofitsiinyi sait vsesvitnoï radi z turizmu ta podorozhey [World Travel \& Tourism Council]. www.wttc.org Retrieved from https://www.wttc.org/ [in English]. 